ISSN 0258-7122

Bangladesh J. Agril. Res. 39(1): 127-141, March 2014

\title{
CABBAGE (Brassica oleracea) AND CAULIFLOWER (Brassica oleracea) MARKETING IN SELECTED AREAS OF BANGLADESH
}

\author{
M. S. HoQ ${ }^{1}$, M. A. MATIN ${ }^{2}$, T. M. B. HosSAIN ${ }^{3}$ AND S. HossAIN ${ }^{4}$
}

\begin{abstract}
The study was conducted in two districts Comilla and Jessore to examine the marketing chain, marketing cost, and margin, problems and some probable solutions for cabbage and cauliflower marketing. A total of 92 respondents consisting of 20 vegetable growers and 72 vegetables traders were selected as sample for the present study. A multi-stage simple random sampling technique was used for selection of samples. Both primary and secondary data were used for the study. About $60 \%$ farmers used van to carry the vegetables to the market. Average cauliflower marketing cost of farmer was higher than cabbage which was Tk.36.59 per quintal due to its special transportation arrangement. On the basis of the intermediaries, seven marketing chain were identified as a dominant. The chain Farmer $\rightarrow$ Local Traders (Faria) $\rightarrow$ Bepari $\rightarrow$ Aratdar (urban) $\rightarrow$ Retailer (urban) $\rightarrow$ Consumer was identified as most dominant. About $39.60 \%$ product runs through this chain. In cauliflower marketing local traders, Bepari, retailer (urban) and retailer (rural) incurred the highest marketing cost than cabbage which were averaged Tk.65.75, Tk.248.47, Tk.205.69, and Tk.78.21, respectively, due to its perishable nature. In the case of farmers, local traders (Faria) and Bepari transportation cost is the highest. Commission charge was highest in the case of retailer (urban) and spoilage and damage cost was the highest for retailer(rural).The marketing cost was the highest for Bepari which were estimated Tk.212.74 for cabbage, Tk.219.87 for cauliflower and the marketing margin was highest for retailer (urban) which were estimated Tk.108.52 for cabbage and Tk.130.09 for cauliflower. Inadequate storage facilities and dominance of intermediaries were the major marketing problems identified by the farmers. Unstable price, barrier to entry in the terminal market, delays on ferryghat and spoilage and damage were the major marketing problem faced by the different intermediaries. The study suggested improving the storage facilities and establishment of organization to solve marketing problem of the farmers. Easy access of vegetables carrying vehicle in the terminal market, arrangement of separate cargo ferry would reduce the spoilage and damage of vegetables in the trader's level.
\end{abstract}

Keywords: Cabbage, cauliflower, marketing chain, marketing cost and net margin.

${ }^{1}$ Scientific Officer, ${ }^{2}$ Principal Scientific Officer, ${ }^{3}$ Senior Scientific Officer and ${ }^{4}$ Chief Scientific Officer, Agril. Econ. Division, Bangladesh Agricultural Research Institute (BARI), Gazipur, Bangladesh. 


\section{Introduction}

Bangladesh is an agro-economy based country. Vegetable production is very suitable here due to fertile land and environment. Vegetable contributes an important share to the total agricultural export in Bangladesh. Vegetables and crops sub-sector also contributes an important share to the agricultural GDP which is near about $9.71 \%$ (Bangladesh Economic Review-2013).

More than 90 different vegetables are grown in Bangladesh. Vegetables are grown in about 4.52 lakh hectares of cultivated land in Bangladesh. Current production of vegetables is about 3.06 million $\mathrm{mt}$. In the year 2010-2011, national production of winter vegetables were 1.59 million $\mathrm{mt}$ and production area were 1.90 lakh hectares. In the year 2010-11, national production of cauliflower and cabbage were 1.68 lakh $\mathrm{mt}$ and 2.07 lakh $\mathrm{mt}$, respectively, and production area were 0.165 lakh hectares and 0.158 lakh hectares, respectively, (BBS 2011). So, cabbage and cauliflower contributes $23.58 \%$ of the total winter vegetables production. Vegetables play an important role in solving the problems of food production and providing a balance diet. Vegetables not only meet home requirements but also the important source of income for the farmers and traders. To recover people from malnutrition, consumption of vegetables need to be increased. So, vegetables play a significant role in nutritional improvement, employment generation, food and financial security of the people of Bangladesh.

The cole crops reduce the risk of cancer, particularly cancer of alimentary canal and respiratory tract. The cole crop, a very important group of winter season vegetables, includes cauliflower, cabbage, khol rabi, broccoli, brussels, sprouts, and chinese cabbage (M. K. wadhwani and T. S. Bhogal, 2003). Of these, cabbage and cauliflower are the two most important winter vegetables grown in Bangladesh.

Cabbage and cauliflower are the important source of vitamin A, C, and $\mathrm{K}$, iron, and calcium, etc. which are important to the consumer as a nutritional value. Production and marketing of such vegetables are labour intensive and these create more employment opportunities. Although several studies have been conducted earlier to highlight the socio-economic consequences and problem and prospect of different vegetables. But the number of marketing studies of the proposed vegetables is very scanty. So, the present attempt has been made to focus the cost and margin of the different levels through the marketing chain, Problems and solutions which will fill gap in the marketing study arena.

\section{Objectives of the study were to:}

1. know the marketing cost and mode of transportation at farmer's level;

2. identify the major marketing chain of cabbage and cauliflower; 
3. estimate marketing cost and margin at different levels of intermediaries, and

4. identify the major marketing problems and suggest for upgrade the system.

\section{Materials and Method}

\section{(a) Sampling technique adopted}

Two winter vegetables, namely cabbage and cauliflower were selected from the two districts, such as Comilla and Jessore of Bangladesh on the basis of intensive growing area of the selected vegetables. Major consuming area was selected as Farmgate in Dhaka city. A total of 92 respondents consisting of 20 vegetable growers and 72 vegetable traders were selected as sample from two areas. Out of 20 vegetables growers taking 10 from each district and out of 72 vegetable traders taking 36 from each district were purposively selected for the present study. As sample size 5 farmers, 4 local traders (Faria), 4 Bepari, 4 Arathdar, and 6 retailers ( 3 rural +3 urban) for each vegetable of each area were selected. Thus the total sample size was 20 farmers, 16 Farias, 16 Beparis, 16 Arathdars, and 24 retailers for the study.

\section{(b) Method of data collection and period of study}

Data related to the vegetables were collected from both primary and secondary sources. Researcher himself conducted the survey and collected primary data through direct interview with respondents. The secondary data were collected from renowned national and international organizations, journals, articles, reports, and internet files. For the study, data were collected during the period from January to March 2012. The data were collected through face to face interview with the respondent.

\section{(c) Analytical technique adopted}

\section{Marketing margin}

Marketing margin included marketing cost and profit or loss of all intermediaries in the marketing chain. For determining marketing margin of any commodity, the following formula was used:

$\mathrm{GM}_{\mathrm{ij}}=\mathrm{PR}_{\mathrm{ij}}-\mathrm{PP}_{\mathrm{ij}}$

Where,

$\mathrm{GM}_{\mathrm{ij}}=$ Gross margin (Tk/quintal) for ith intermediary of $\mathrm{jth}$ vegetables.

$\mathrm{PR}_{\mathrm{ij}}=$ Price received (Tk/quintal) for ith intermediary of jth vegetables.

$\mathrm{PP}_{\mathrm{ij}}=$ Price paid (Tk/quintal) by ith intermediary of jth vegetables.

and, $\mathrm{NM}_{\mathrm{ij}}=\mathrm{GM}_{\mathrm{ij}}-\mathrm{MC}_{\mathrm{ij}}$.

Where, 
$\mathrm{NM}_{\mathrm{ij}}=$ Net margin (Tk./quintal) for ith intermediary of $\mathrm{jth}$ vegetables.

$\mathrm{MC}_{\mathrm{ij}}=$ Marketing cost incurred (Tk./quintal) by ith intermediary of $\mathrm{jth}$ vegetables.

\section{Results and Discussion}

\section{Marketing cost of selected vegetables by farmer}

Farmers are the starting point of the marketing. Farmers used different means of transportation to carry selected vegetables for sale in the market. It was revealed from Table 1 that, on an average, $60 \%$ vegetables growers used van and $20 \%$ farmers used van with diesel engine. The other modes of transportation were head and shoulder, rickshaw, and bye-cycle.

Table 1. Mode of transportation used by the farmer in the study area.

(Tk./quintal)

\begin{tabular}{l|c|c|c}
\hline \multirow{2}{*}{ Mode of Transport } & \multicolumn{3}{|c}{ \% of Farmer } \\
\cline { 2 - 4 } & Comilla & Jessore & Average \\
\hline Head and shoulder & 10 & 10 & 10 \\
Rickshaw & 10 & 5 & 7.5 \\
Bye-cycle & 0 & 5 & 2.5 \\
Van & 60 & 60 & 60 \\
Van with diesel engine & 20 & 20 & 20 \\
\hline
\end{tabular}

It was observed from the Table 2 that the average marketing cost of cauliflower was higher than cabbage, which was Tk. 36.59 per quintal because of its flowering system. For this, cauliflower needs special transportation arrangement. For cabbage, the marketing cost was Tk.28.85 per quintal. This cost varied from vegetable to vegetable. Transportation cost was the major cost item for both of the vegetables and followed by market toll, personal cost, and sweeper cost, respectively.

Table 2. Marketing cost of selected vegetables by farmer in all areas.

(Tk./quintal)

\begin{tabular}{l|c|c|c|c}
\hline \multirow{2}{*}{ Marketing cost item } & \multicolumn{2}{|c|}{ Cabbage } & \multicolumn{2}{c}{ Cauliflower } \\
\cline { 2 - 5 } & Average cost & $\begin{array}{c}\text { \% of total } \\
\text { cost }\end{array}$ & Average cost & \% of total cost \\
\hline Transportation & 17.4 & 60.31 & 22.04 & 60.24 \\
Market toll & 4.10 & 15.44 & 5.47 & 14.96 \\
Sweeper & 2.35 & 8.15 & 1.80 & 4.92 \\
Personal cost & 5.00 & 17.33 & 7.28 & 19.88 \\
Total & 28.85 & 100 & 36.59 & 100 \\
\hline
\end{tabular}




\section{Marketing chain}

Marketing chain is the alternative root of products flow from producers to consumers (Khols and Uhl, 1980). In the study areas, selected winter vegetables are moved from producer to consumer in the different markets through different intermediaries, such as Faria, Beparies, Arathdar, Paiker, and retailers (Both rural and urban). According to the transacted volume of the selected winter vegetables and participations of the intermediaries in the channel, seven major channels were identified in the study areas.

Table 3. Major marketing chain of selected vegetables.

\begin{tabular}{|c|c|c|c|}
\hline & Marketing chain & $\begin{array}{l}\text { Percent of product } \\
\text { run }\end{array}$ & Rank \\
\hline 1. & $\begin{array}{l}\text { Farmer } \rightarrow \text { Local Traders }(\text { Faria }) \rightarrow \text { Bepari } \rightarrow \text { Aratdar } \\
(\text { urban) } \rightarrow \text { Retailer (urban) } \rightarrow \text { Consumer }\end{array}$ & 39.60 & I \\
\hline 2. & $\begin{array}{l}\text { Farmer } \rightarrow \text { Bepari } \rightarrow \text { Aratdar (urban) } \rightarrow \text { Retailer (urban) } \\
\rightarrow \text { Consumer }\end{array}$ & 25.40 & II \\
\hline 3. & $\begin{array}{l}\text { Farmer } \rightarrow \text { Local Traders (Faria) } \rightarrow \text { Bepari } \rightarrow \text { Retailer } \\
(\text { rural }) \rightarrow \text { Consumer }\end{array}$ & 18.25 & III \\
\hline & $\begin{array}{l}\text { Farmer } \rightarrow \text { Local Traders (Faria) } \rightarrow \text { Bepari } \rightarrow \text { Aratdar } \\
(\text { rural }) \rightarrow \text { Aratdar (urban) } \rightarrow \text { Retailer }(\text { urban }) \rightarrow \\
\text { Consumer }\end{array}$ & 7.17 & IV \\
\hline & $\begin{array}{l}\text { Farmer } \rightarrow \text { Bepari } \rightarrow \text { Aratdar (rural) } \rightarrow \text { Aratdar (urban) } \\
\rightarrow \text { Retailer (urban) } \rightarrow \text { Consumer }\end{array}$ & 5.83 & $\mathrm{~V}$ \\
\hline & Farmer $\rightarrow$ Retailer (rural) $\rightarrow$ Consumer & 3.00 & VI \\
\hline \multirow{2}{*}{\multicolumn{2}{|c|}{ 7. Farmer $\rightarrow$ Consumer }} & 0.75 & VII \\
\hline & & 100 & \\
\hline
\end{tabular}

\section{Marketing costs and margins of selected vegetables}

The cost of marketing represents the cost of performing the various marketing functions and operations by various agencies involved in the marketing process (Kohls and Uhl, 1980). In other words, the costs, which are incurred to move the product from producers to consumers, are ordinarily known as marketing cost.

\section{Marketing cost of selected vegetables by local traders (Faria)}

Table 4 shows the marketing costs of local traders (Faria) of two vegetables. Transportation, loading, unloading, market toll, rent, entertainment, telephone, and mobile phone cost were the major cost items of the local traders (Faria). The average marketing cost of cabbage and cauliflower were Tk.49.24 and Tk.54.40 per quintal, respectively, by the local traders (Faria). Among the cost items, transportation cost was the highest for each vegetable. Local traders (Faria) 
incurred the highest marketing cost in the case of cauliflower marketing due to its perishable nature.

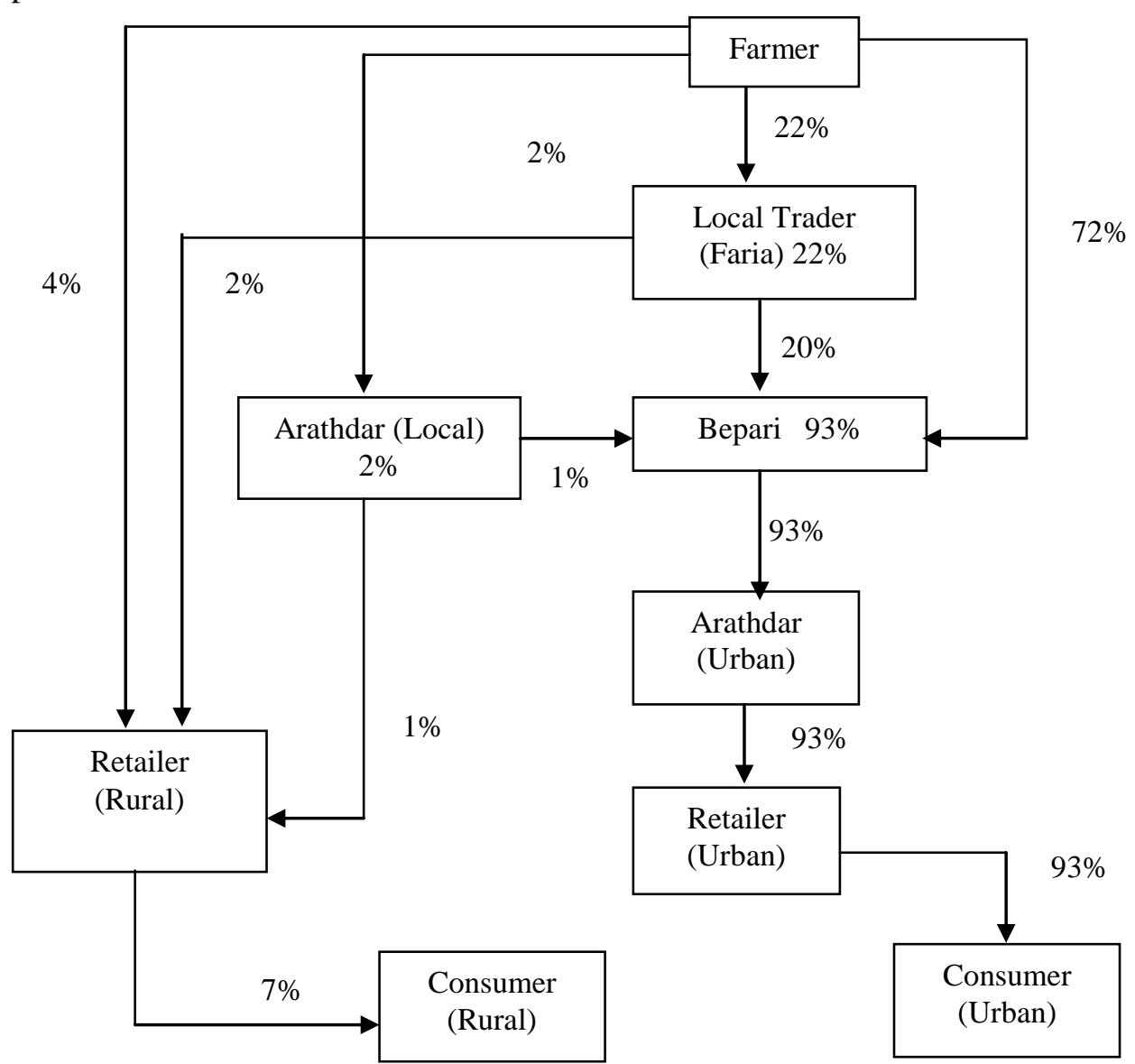

Fig. 1. Marketing chain of selected winter vegetables.

Table 4. Marketing cost of selected vegetables by local traders (Faria) in all area.

(Tk/quintal)

\begin{tabular}{l|cc|c|c}
\hline \multirow{2}{*}{ Marketing cost item } & \multicolumn{2}{|c|}{ Cabbage } & \multicolumn{2}{c}{ Cauliflower } \\
\cline { 2 - 5 } & Average cost & \% of total cost & Average cost & \% of total cost \\
\hline Transportation & 17.42 & 35.37 & 20.70 & 38.05 \\
Loading \& unloading & 12.70 & 25.79 & 13.60 & 25.00 \\
Market toll & 6.85 & 13.90 & 7.08 & 13.01 \\
Rent & 7.45 & 15.13 & 7.75 & 14.25 \\
Entertainment & 3.80 & 7.72 & 4.00 & 7.35 \\
Telephone/ Mobile & 1.03 & 2.08 & 1.28 & 2.34 \\
\hline Total & 49.24 & 100.00 & 54.40 & 100.00 \\
\hline
\end{tabular}




\section{Marketing cost of selected vegetables by Bepari}

Table 5 shows the marketing cost of Bepari of two vegetables in all areas. Beparies incurred the highest marketing cost than other intermediaries due to their large business volume and transportation cost. The average marketing cost of cabbage and cauliflower were Tk.212.74 and Tk.219.87 per quintal, respectively. The average marketing costs of cauliflower was higher than cabbage due to it perishable nature. Transportation cost was the major cost item of Beparies which covered about $44 \%$ of the total marketing cost. It followed by commission charge, spoilage and damage, packaging, loading and unloading in case of all selected vegetables. Other cost items were market toll, rent, mobile phone cost, personal expenses, subscription etc.

Table 5. Marketing cost of selected vegetables by Bepari in all area.

(Tk./quintal)

\begin{tabular}{l|c|c|c|c}
\hline \multirow{2}{*}{\multicolumn{1}{c|}{ Marketing cost item }} & \multicolumn{2}{c|}{ Cabbage } & \multicolumn{2}{c}{ Cauliflower } \\
\cline { 2 - 5 } & $\begin{array}{c}\text { Average } \\
\text { cost }\end{array}$ & $\begin{array}{c}\text { \% of total } \\
\text { cost }\end{array}$ & Average cost & $\begin{array}{c}\text { \% of total } \\
\text { cost }\end{array}$ \\
\hline Transportation & 93.25 & 43.83 & 95.85 & 43.59 \\
Loading \& unloading & 10.89 & 5.12 & 12.61 & 5.74 \\
Packaging & 12.43 & 5.84 & 13.30 & 6.05 \\
Spoilage and damage & 15.38 & 7.23 & 17.45 & 7.94 \\
Market toll & 8.50 & 4.00 & 7.79 & 3.54 \\
Rent & 9.40 & 4.42 & 9.60 & 4.37 \\
Arathder (commission) & 45.00 & 21.15 & 43.50 & 19.78 \\
Telephone/Mobile phone cost & 3.20 & 1.50 & 3.02 & 1.37 \\
Entertainment/Personal & 9.75 & 4.58 & 10.57 & 4.81 \\
expenses & 4.95 & 2.33 & 6.18 & 2.81 \\
Subscription & 212.74 & 100.00 & 219.87 & 100.00 \\
\hline Total & \multicolumn{3}{c}{} \\
\hline
\end{tabular}

\section{Marketing cost of selected vegetables by retailer (Urban)}

Marketing cost of the retailers (Urban) is shown in the following Table (Table 6). Commission to the Arathdar was the major cost item of the urban retailer which constituted $36 \%$ of the total cost of all selected vegetables. The next highest cost items were transportation, spoilage and damage, loading and unloading, possession rent, entertainment, shopping bag, electricity, and telephone/mobile cost for the retailer (Urban). Retailer (Urban) incurred the highest cost in cauliflower marketing which was encounted for Tk.176.20 per quintal and Tk.168.32 for cabbage per quintal. 
Table 6. Marketing cost of retailer (Urban).

(Tk./quintal)

\begin{tabular}{l|ccc|c|c}
\hline \multirow{2}{*}{ Marketing cost item } & \multicolumn{2}{c|}{ Cabbage } & \multicolumn{2}{c}{ Cauliflower } \\
\cline { 2 - 5 } & Cost (Tk.) & $\%$ of total cost & Cost (Tk.) & $\%$ of total cost \\
\hline Transportation & 52.90 & 31.43 & 53.55 & 30.39 \\
Loading and unloading & 13.20 & 7.84 & 12.10 & 6.87 \\
Commission & 60.60 & 36.00 & 64.60 & 36.66 \\
Spoilage and damage & 26.18 & 15.55 & 30.28 & 17.19 \\
Possession rent & 9.49 & 5.64 & 9.49 & 5.39 \\
Electricity & 0.85 & 0.50 & 0.82 & 0.47 \\
Shopping bag & 1.35 & 0.80 & 1.56 & 0.89 \\
Entertainment & 3.25 & 1.93 & 3.10 & 1.76 \\
Telephone/mobile & 0.50 & 0.30 & 0.70 & 0.40 \\
\hline Total & 168.32 & 100.00 & 176.20 & 100.00 \\
\hline
\end{tabular}

\section{Marketing cost of selected vegetables by retailer (Rural)}

Marketing cost of retailer (Rural) in two areas was depicted in Table 7. It was revealed from the study that per quintal average marketing cost was Tk.72.71 for cauliflower, which was higher than cabbage. Among all the cost items, spoilage and damage cost is the highest which constituted about $42-46 \%$ of the total marketing cost because of selling small amount during long period. The next highest cost items were the loading and unloading, transportation, possession rent, entertainment, shopping bags, etc., respectively.

Table 7. Marketing cost of selected vegetables by retailer (rural) in all area.

(Tk./quintal)

\begin{tabular}{l|cc|c|c}
\hline \multirow{2}{*}{ Marketing Cost item } & \multicolumn{2}{|c|}{ Cabbage } & \multicolumn{2}{c}{ Cauliflower } \\
\cline { 2 - 5 } & Average cost & \% of total cost & Average cost & \% of total cost \\
\hline Transportation & 10.89 & 18.04 & 12.90 & 17.73 \\
Loading \& unloading & 11.92 & 19.75 & 13.75 & 18.91 \\
Possession rent & 7.70 & 12.76 & 7.70 & 10.59 \\
Electricity & 0.7 & 1.16 & 0.70 & 0.96 \\
Spoilage and damage & 25.65 & 42.50 & 33.31 & 45.81 \\
Entertainment & 1.625 & 2.69 & 1.93 & 2.65 \\
Telephone/Mobile cost & 0.6 & 0.99 & 0.73 & 1.00 \\
Shopping bags & 1.28 & 2.11 & 1.70 & 2.34 \\
\hline Total & 60.36 & 100.00 & 72.71 & 100 \\
\hline
\end{tabular}




\section{Marketing cost of Arathdar}

Arathdar is the commission agent who has a fixed establishment and operates between Bepari and retailers or between farmer and Paiker or between Bepari and Paiker. That is why their cost items differ from the other intermediaries and their marketing cost is shown in Table 8. They take commission from both Beparies and urban retailers but generally, they do not follow any standard rule to take commission. The total marketing cost of Arathdar for two vegetables was found Tk.50.62 per quintal. Wages and salaries to the employee was the major cost item found among the cost item which constituted $55.31 \%$ of the total cost.

Table 8. Marketing cost of Arathdar.

(Tk./quintal)

\begin{tabular}{lcc}
\hline \multicolumn{1}{c|}{ Cost items } & Average cost & \% of total cost \\
\hline Wages and salaries to the employees & 28.00 & 55.31 \\
Shop rent & 6.67 & 13.18 \\
Weighing charge & 8.00 & 15.80 \\
Sweeper & 0.14 & 0.28 \\
Personal expenses/Entertainment & 6.11 & 12.07 \\
Electricity cost & 1.10 & 2.17 \\
Mobile/Telephone & 0.60 & 1.19 \\
\hline Total & 50.62 & 100.00 \\
\hline
\end{tabular}

\section{Marketing margin}

Generally marketing margin is the difference between the price paid by the consumer and price received by the producers. Marketing margin has two components marketing cost and net margin or profit. In broad sense, marketing margin is the difference between what is paid by the consumer and what is received by the producer. It is the price of all utility adding activities and functions that are performed by the intermediaries (Kohls and Uhl, 1980).

\section{Marketing margin of cabbage:}

It was revealed from Table 9 that net margin or profit of the local traders (Faria), Bepari, retailer (Urban), and retailer (Rural) was Tk.34.00, Tk.100.00, Tk.108.52, and Tk.64.14 per quintal, respectively. The net margin of retailer (Urban) was the highest, which was Tk.108.52 per quintal followed by Bepari, retailer (Rural) and local traders (Faria). 
Table 9. Marketing margin of cabbage for different intermediaries.

\begin{tabular}{l|c|c|c|c|c}
\hline $\begin{array}{c}\text { Types of } \\
\text { Intermediaries }\end{array}$ & Sales price & $\begin{array}{c}\text { Purchase } \\
\text { price }\end{array}$ & $\begin{array}{c}\text { Marketing } \\
\text { margin }\end{array}$ & $\begin{array}{c}\text { Marketing } \\
\text { cost }\end{array}$ & Net margin \\
\hline Farmer & 710.00 & 0 & 0 & 0 & 0 \\
Faria & 793.24 & 710.00 & 83.24 & 49.24 & 34.00 \\
Bepari & 1105.98 & 793.24 & 312.74 & 212.74 & 100.00 \\
Retailer (urban) & 1382.82 & 1105.98 & 276.84 & 168.32 & 108.52 \\
Retailer (rural) & 720.00 & 844.50 & 124.50 & 60.36 & 64.14 \\
\hline
\end{tabular}

\section{Marketing margin of cauliflower}

The net margin or profit of the local traders (Faria), Bepari, retailer (Urban), and retailer (Rural) was Tk.55.60, Tk.101.88, Tk.130.09, and Tk.65.49 per quintal, respectively. Net margin is also highest for retailer (Urban) in case of cauliflower marketing, which was Tk.130.09 per quintal. The next highest margin was received by Bepari, retailer (Rural), and local traders (Faria) (Table 10).

Table 10. Marketing margin of cauliflower for different intermediaries.

(Tk./quintal)

\begin{tabular}{lcccccc}
\hline $\begin{array}{c}\text { Types of } \\
\text { Intermediaries }\end{array}$ & Sales price & $\begin{array}{c}\text { Purchase } \\
\text { price }\end{array}$ & $\begin{array}{c}\text { Marketing } \\
\text { margin }\end{array}$ & $\begin{array}{c}\text { Marketing } \\
\text { cost }\end{array}$ & Net margin \\
\hline Farmer & 912.00 & 0 & 0 & 0 & 0 \\
Faria & 1022.00 & 912.00 & 110.00 & 54.40 & 55.60 \\
Bepari & 1343.75 & 1022.00 & 321.75 & 219.87 & 101.88 \\
Retailer (Urban) & 1650.66 & 1343.75 & 306.91 & 176.82 & 130.09 \\
Retailer (Rural) & 992.00 & 1130.20 & 138.20 & 72.71 & 65.49 \\
\hline
\end{tabular}

\section{Marketing margin of Arathdar}

Arathdars obtained more or less same profit for marketing of the two vegetables which is shown in the Table 10. The net margin of Arathdar is Tk.26.73 for cabbage and Tk.26.38 for cauliflower.

Table 10. Profit of selected vegetables by Arathdar.

\begin{tabular}{l|c|c|c}
\hline \multirow{2}{*}{ Name of vegetables } & \multicolumn{3}{|c}{ Tk./quintal } \\
\cline { 2 - 4 } & Marketing margin & Marketing cost & Net margin \\
\hline Cabbage & 77.35 & 50.62 & 26.73 \\
Cauliflower & 77.00 & 50.62 & 26.38 \\
\hline
\end{tabular}


Marketing cost (MC), Gross marketing margin (GM) and profit distribution of different intermediaries of selected vegetables

Marketing cost (MC), Gross marketing margin (GM), and profit of different intermediaries for cabbage and cauliflower are presented in Table 11. The net margin or profit of retailer (Urban) was the highest for both of the vegetables followed by Bepari, retailer (Rural), local traders (Faria) and Arathdar.

It indicate retailer (Urban) makes highest profit because they sale small amount by keeping long time.

Table 11. Marketing cost (MC), gross marketing margin (GM) and profit of different intermediaries of cabbage and cauliflower.

(Tk./quintal)

\begin{tabular}{l|c|c|c|c|c|c}
\hline \multirow{2}{*}{$\begin{array}{c}\text { Types of } \\
\text { intermediaries }\end{array}$} & \multicolumn{3}{c|}{ Cabbage } & \multicolumn{3}{c}{ Cauliflower } \\
\cline { 2 - 7 } \multicolumn{1}{c}{ MC } & GM & Profit & MC & GM & Profit \\
\hline Local traders (Faria) & 49.24 & 83.24 & 34.00 & 54.40 & 110.00 & 55.60 \\
Bepari & 212.74 & 312.74 & 100.00 & 219.87 & 321.75 & 101.88 \\
Arathdar & 50.62 & 77.35 & 26.73 & 50.62 & 77.00 & 26.38 \\
Retailer (Urban) & 168.32 & 276.84 & 108.52 & 176.82 & 306.91 & 130.09 \\
Retailer (Rural) & 60.36 & 124.50 & 64.14 & 72.71 & 138.20 & 65.49 \\
\hline
\end{tabular}

\section{Problems and solutions of vegetable marketing}

The present study was undertaken to identify the major problems faced by farmers and intermediaries who were involved in vegetables marketing. The problems of vegetable marketing were identified based on opinion of the related parties.

Marketing problems faced by the farmers: Farmers faced the following problems during the marketing of vegetables.

Table11. Marketing problem identified by the farmers.

\begin{tabular}{l|c|c|c}
\hline \multirow{2}{*}{\multicolumn{1}{c|}{ Marketing problems }} & \multicolumn{3}{c}{ \% of respondent (Farmers) } \\
\cline { 2 - 4 } & Comilla & Jessore & All area \\
\hline Inadequate storage facilities & 60 & 76 & 68 \\
Lack of marketing facilities & 50 & 48 & 49 \\
Lack of market information & 58 & 64 & 61 \\
Dominance of intermediaries & 66 & 42 & 54 \\
\hline
\end{tabular}

Inadequate storage facilities: In the study areas, there was no sufficient storage facility for keeping vegetables for the time being. So, lack of storage facility was 
a problem that caused damage of these perishable vegetables especially cabbage and cauliflower during the peak season.

Lack of marketing facilities: There was no shed to protect the farmer's vegetables from rain or sun and the farmers had to sell their produce standing in the open place. So, lack of market facilities such as pucca floor, tin shed, drainage, water supply were mentioned as problems by vegetable farmers $(49 \%)$.

Lack of market information: Farmers did not get the price related information properly. As a result, they did not get fair prices of their produce as compared to terminal market. Majority of the farmers have reported the problems (61\%).

Dominance of intermediaries: In the local markets, intermediaries were small in number but organized. Moreover, the farmers were scattered and large in number. So, intermediaries always dominated the marketing system and they were in better position in determining price than the farmers. Due to the dominance of intermediaries in the local markets, farmers compelled to sell their vegetables at a lower price. Because vegetables are highly perishable commodities. About 54\% farmers reported it as a problem.

Marketing problems faced by intermediaries: The intermediaries were asked to mention the problems they faced in vegetables business, especially, relating to marketing. They encountered the following problems during marketing (Table 12).

Table 12. Marketing problem identified by the traders.

\begin{tabular}{l|c|c|c}
\hline \multirow{2}{*}{\multicolumn{1}{c}{ Marketing problems }} & \multicolumn{3}{c}{$\%$ of respondent (Traders) } \\
\cline { 2 - 4 } & Comilla & Jessore & All area \\
\hline Shortage of capital & 50 & 48 & 49 \\
Price instability & 62 & 54 & 58 \\
Barrier to entry in the terminal Market & 64 & 34 & 49 \\
Delay on ferighat & 0 & 70 & 35 \\
Weight loss and damage & 52 & 60 & 56 \\
High amount of Charge & 42 & 38 & 40 \\
\hline
\end{tabular}

Shortage of capital: About $49 \%$ intermediaries reported that inadequate capital arose as a problem to run their business smoothly. Because a Bepari had to supply 4-5 tones of vegetables per day. So, it required huge amount of capital. For this Beparies always had to depend on Arathdars for their capital support.

Price instability: Price instability was one of the major problems of the intermediaries. Because price varied different times within a day. Because of price instability the intermediaries got lower profit. 
Barrier to entry in the terminal market: About $49 \%$ of the intermediaries (Bepari) reported that they cannot enter terminal market properly due to excessive formalities, such as traffic police create hamper if they fail to enter in the city within 8.00 p.m. As a result, they have to wait a long in the road side for the permission of traffic police.

Delay on ferryghat: The intermediaries (35\%) of Jessore reported that they have to wait a long in the ferighat to send their vegetables in the Dhaka city due to lack of sufficient ferry. As a result, spoilage and damage largely depends on the unavailability of ferry.

Weight loss and damage: Weight loss and damage were major problem of the intermediaries (56\%). Grading, packing, and transportation reduced the marketed volumes by weight loss and damage. It increased cost and reduced profit.

High amount of charges: The intermediaries (40\%) reported that high amount of charges arose as a problem to run their business smoothly. They had to provide high amount of tax and toll to the market authority.

\section{Conclusion}

Cabbage and cauliflower are very much perishable among the vegetables and needs immediate marketing. The aim of the study is to know the marketing chain, cost and margin of different intermediaries involved in the chain and to identify Marketing problems associated with the growers and intermediaries of cabbage and cauliflower marketing. It was revealed from the study that most of farmers used van to carry the vegetables to the market. Van and van with diesel engine were two major mode of transportation used by the farmers. Seven major marketing chains were identified of vegetables marketing in the study area. The chain Farmer $\rightarrow$ Local traders (Faria) $\rightarrow$ Bepari $\rightarrow$ Aratdar (urban) $\rightarrow$ Retailer (urban) $\rightarrow$ Consumer was ranked at first position. About $39.60 \%$ percent product runs through this chain. Several intermediaries were involved in studied vegetables marketing and marketing cost was incurred by these intermediaries for different marketing functions. Beparies incurred the highest marketing cost than other intermediaries due to their large business volume. Marketing cost of cauliflower was higher than that of cabbage because it was more perishable than cabbage. A good amount of marketing margin was added by all kinds of intermediaries involved in the cabbage and cauliflower marketing. The net marketing was the highest for retailer (Urban) and the lowest for Arathdar. Transportation and commission charge were the major cost items both for Bepari and retailer (Urban) in the marketing of two vegetables. Inadequate storage facilities lack of market information and dominance of intermediaries were the major marketing problems identified by the farmers. 


\section{Recommendation of the study}

Based on the findings of the study the following recommendations were made to improve the present marketing system of vegetables.

- Transportation facilities should be improved in the rural areas at least brick bedded. On the basis of priority village roads should be developed at least brick bedded road should be made so that the rickshaw, van, truck and other vehicles could move easily. It would also help reducing the transportation cost.

- Government should try to help farmers by ensuring a fair price. Farmers will increase their production if they know that there is a guaranteed price and market.

- Farmer's organization should be established which might improve the bargaining power of the farmers, enabling them to face the intermediaries and ensuring better return for their produce. In addition to these market toll should be fixed at a reasonable level.

- Institutional credit on easy terms as a measure for solution of problem of capital shortage in case of vegetables trading. There are mainly banks and other types of financial institutional such as credit unions, savings and credit cooperatives and various types of microfinance organizations.

- Payment should be made in cash. Improving ways of handling of vegetables produce is a measure to minimize product losses. Improving transportation system, grading and packaging also reduced the wastage of vegetables.

- Modern storage facilities (such as cold storage) should be developed considering the economic feasibility, cold storage may established at important assemble centre.

- Vegetables carrying vehicle should required easy access in the terminal market due to reduce spoilage and damage.

- Separate cargo ferry should be arranged in the ferryghat so that traders could easily send their products in the terminal market.

\section{Foot note}

Local traders (Faria): Faria is a petty trader who purchases vegetables from the producer in the village or in the local market and offer the same to the bepari. Sometimes he sells his produce directly to the rural retailer or consumers.

Bepari: Bepari is a professional wholesale trader who make his purchase from producer at the local market, bring their consignment to the urban wholesale 
market and sell them to the paiker and retailer through arathdar (Commission agent).Sometimes he buys vegetables from the faria in local market.

Arathdar: Arathdar is a commission agent who has a fixed establishment and operates between bepari and retailers, or between farmer and paiker, or between bepari and paiker.

Paiker: Wholesaler in consuming area is known as paiker, who purchase vegetables from bepari through arathdar and sell those to the retailer or consumer.

Retailer: The retailer, the last link in the marketing channel, buys vegetables from arathdar or wholesaler and sells these to the consumer.

Definitions of intermediaries are taken from Huq et al. (2004)

\section{References}

BBS. 2011. Year Book of Agricultural statistics of Bangladesh, Ministry of Planning, Government of the People's Republic of Bangladesh, Dhaka.

Huq, A.S.M.A., S. Alam and S. Akter. 2004. Marketing efficiency of different channels for potato in selected areas of Bangladesh, Bangladesh Journal of Agricultural Economics 27(1):67-79

Kohls, R. L. and J. N. Ohl. 1980. Marketing of Agricultural Products, (5 ${ }^{\text {th }}$ edition), Macmillan Publishing Co. Inc., New York.

MoF. 2013. Bangladesh Economic Review, Economic Advisors Wings, Finance Division, Ministry of Finance, Government of the People's Republic of Bangladesh, Dhaka.

Matin, M.A., M. R. Karim, M. I. Hossain and M. A. Hossain. 2008.Tomato marketing system in Bangladesh. Bangladesh J. Agril. Res. 33(1):67-81.

Mushtaq Ahmed, A. K. M. H. Haque, M. A. Matin and M. I. Hossain. 1990. Winter Vegetables marketing system in selected areas of Bangladesh, Annual report, Agricultural Economics Division, Bangladesh Agricultural Research Institute, Joydebpur, Gazipur.

Wadhwani, M. K. and T. S. Bhogal. 2003. Economics of Production, Post-harvest Management and Price Behaviour of Cole crops in Western UP-An Empirical Analysis, A National Level Quarterly Journal on Agricultural Marketing, Directorate of Marketing \& Inspection, Ministry of Agriculture, Government of India, VolXLVI, No. 1 